\title{
Hubungan umur dan pekerjaan ibu menyusui dengan pemberian ASI eksklusif
}

\author{
Rolita Efriani, ${ }^{1 *}$ Dhesi Ari Astuti ${ }^{2}$ \\ 1, 2Program Magister Kebidanan, Fakultas Kesehatan, Universitas ‘Aisyiyah Yogyakarta - \\ Indonesia
}

\begin{abstract}
One of the efforts of the United Nations Children's Fund (UNICEF) and the World Health Organization (WHO) to reduce the Infant Morbidity and Mortality Rate (IMR) is to recommend that babies should only be breastfed for the first six months of life (exclusive breastfeeding). The coverage of exclusive breastfeeding in the Special Region of Yogyakarta was 73.3\%. The lowest was in the city of Yogyakarta at $59.52 \%$. This achievement had not yet reached the government's target of $80 \%$. Puskesmas Umbulharjo 1 is the health center with the lowest exclusive breastfeeding coverage in Yogyakarta City at 39.15\%. This study aims to determine the relationship between mothers' age and occupation with exclusive breastfeeding at Puskesmas Umbulharjo 1 Yogyakarta City. This research is an analytic survey with a cross-sectional approach. A sample of 64 mothers was taken from a population of 179 mothers who had babies aged 6-12 months. Data were analyzed by using the Chi-Square test. The results of the analysis of maternal age with exclusive breastfeeding obtained a p-value of $0.007(p<0.05)$, while the analysis of maternal age with exclusive breastfeeding showed a $p$-value of $0.000(p<0.05)$. In conclusion, there is a relationship between the mother's age and occupation and exclusive breastfeeding in the working area of Puskesmas Umbulharjo 1 Yogyakarta City.
\end{abstract}

Keywords: age; breastfeeding mothers; exclusive breastfeeding; work

\begin{abstract}
Salah satu upaya United Nations Children's Fund (UNICEF) dan World Health Organization (WHO) dalam rangka untuk menurunkan Angka Kesakitan dan Kematian Bayi (AKB) adalah merekomendasikan bahwa sebaiknya bayi hanya diberi ASI selama enam bulan pertama kehidupan (ASI eksklusif). Cakupan pemberian ASI eksklusif di Daerah Istimewa Yogyakarta sebesar 73,3\% dan terendah berada di Kota Yogyakarta sebesar $59,52 \%$, pencapaian tersebut belum mencapai target pemerintah yaitu sebesar 80\%. Puskesmas Umbulharjo 1 merupakan puskesmas dengan cakupan ASI eksklusif terendah di Kota Yogyakarta sebesar $39,15 \%$. Penelitian ini bertujuan untuk mengetahui hubungan umur dan pekerjaan ibu dengan pemberian ASI eksklusif di Puskesmas Umbulharjo 1 Kota Yogyakarta. Penelitian ini merupakan survey analitik dengan pendekatan cross-sectional. Sampel 64 ibu diambil dari populasi 179 ibu yang mempunyai bayi umur 6-12 bulan. Data dianalisis dengan uji Chi-Square. Hasil analisis umur ibu dengan pemberian ASI eksklusif didapatkan nilai $p$-value $0,007(p<0,05)$ sedangkan analisis pekerjaan ibu dengan pemberian ASI eksklusif didapatkan hasil $p$-value $0,000(p<0,05)$. Kesimpulannya, ada hubungan antara umur dan pekerjaan ibu dengan pemberian ASI eksklusif di wilayah kerja Puskesmas Umbulharjo 1 Kota Yogyakarta.
\end{abstract}

Kata Kunci: umur; ibu menyusui; asi eksklusif; pekerjaan

*Korespondensi Penulis: Rolita Efriani (email: efrianirolita@gmail.com), Mlangi Nogotirto, Jl. Siliwangi Jl. Ringroad Barat No. 63, Gamping, Sleman, Daerah Istimewa Yogyakarta 55592. 


\section{Pendahuluan}

Modal dasar pembentukan manusia berkualitas dimulai sejak janin dalam kandungan dengan memberi nutrisi pada ibu hamil dan dianjurkan pemberian air susu ibu (ASI) secara eksklusif setelah bayi dilahirkan. Pemberian ASI ini sangat penting untuk pertumbuhan dan perkembangan bayi yang optimal. Pemberian ASI perlu mendapat perhatian para ibu dan tenaga kesehatan agar proses menyusui dapat terlaksana dengan baik sebagaimana tertuang dalam Peraturan Pemerintah Nomor 33 Tahun 2012 tentang Pemberian Air Susu Ibu Eksklusif. Selain penting bagi tumbuh kembang bayi, ASI juga dapat meningkatkan kualitas bayi, dengan meningkatnya kualitas bayi maka derajat kesehatan akan meningkat.

Indikator meningkatnya derajat kesehatan dan kesejahteraan masyarakat salah satunya ditandai dengan menurunnya Angka Kematian Bayi (AKB). Sustainable Development Goals (SDG's) menargetkan terjadi penurunan Angka Kematian Bayi (AKB) sekurang-kurangnya 12 per 1.000 kelahiran hidup pada tahun 2030. Berdasarkan Survey Demografi dan Kesehatan Indonesia (SDKI) pada tahun 2012, tercatat bahwa angka kematian bayi di Indonesia yaitu 32 per 1.000 kelahiran hidup, artinya 1 dari 31 bayi meninggal sebelum mencapai usia 1 tahun (SDKI, 2012). Sedangkan hasil SDKI pada tahun 2017 menunjukkan bahwa angka kematian bayi menjadi 24 per 1000 kelahiran hidup. Jumlah ini turun dibandingkan dengan hasil SDKI 2012 (Badan Kependudukan dan Keluarga Berencana Nasional, 2018).

Salah satu upaya United Nation Childrens Fund (UNICEF) dan World Health Organization (WHO) dalam rangka untuk menurunkan Angka Kesakitan dan Kematian Bayi (AKB) dengan merekomendasikan bahwa sebaiknya bayi hanya diberi ASI selama paling sedikit enam bulan. ASI eksklusif dianjurkan pada enam bulan pertama kehidupan karena ASI tidak terkontaminasi dan mengandung banyak gizi yang diperlukan anak pada umur tersebut (UNICEF - Departemen Kesehatan RI Direktorat Jendral Bina Kesehatan Masyarakat Direktorat Gizi Masyarakat, 2009).

Pemberian ASI eksklusif pada tahun 2016 di dunia rata-rata masih sebesar $38 \%$ ibu-ibu yang memberikan ASI eksklusif kepada bayinya. Secara nasional, cakupan bayi mendapat ASI eksklusif tahun 2017 sebesar 61,33\%, dengan demikian dapat dikatakan masih ada sekitar $38,67 \%$ bayi di Indonesia belum terpenuhi haknya untuk memperoleh ASI Eksklusif. Secara nasional capaian pemberian ASI eksklusif di Indonesia belum mencapai target pemerintah yaitu sebesar $80 \%$ pada bayi 0-6 bulan (Kementerian Kesehatan RI., 2018).

Upaya meningkatkan perilaku ibu menyusui masih diperlukan karena pada kenyataannya praktik pemberian ASI eksklusif belum dilakukan sepenuhnya. Pemberian ASI eksklusif dipengaruhi beberapa faktor diantaranya faktor predisposisi (pengetahuan, umur, pekerjaan, pendidikan, paritas dan sosial budaya), faktor pendukung (pendapatan keluarga, ketersediaan waktu dan kesehatan ibu) dan faktor pendorong (dukungan keluarga dan petugas kesehatan (Notoatmodjo, 2003).

Pekerjaan ibu merupakan salah satu faktor yang mempengaruhi keberhasilan dan kegagalan pemberian ASI eksklusif. Data Badan Pusat Statistik (BPS) tahun 2016, menyatakan bahwa 
dari seluruh ibu yang memiliki anak usia di bawah 2 tahun yang sedang menyusui, $31 \%$ diantaranya merupakan ibu yang bekerja di luar rumah. Status atau peran ganda pada perempuan ini yang akan berpengaruh terhadap kesehatan anak-anak mereka. Di satu sisi perempuan harus menjalankan tugasnya sebagai ibu yang bekerja, di sisi lain harus memenuhi hak anaknya untuk mendapatkan ASI guna mencukupi asupan gizi anak agar anak tumbuh dan berkembang dengan baik (BPS, 2016).

Ibu yang bekerja menjadi salah satu kendala dalam menyukseskan program ASI eksklusif karena ibu yang bekerja di luar rumah memiliki keterbatasan kesempatan untuk menyusui bayinya secara langsung. Selain itu, cuti melahirkan hanya 12 minggu, 4 minggu diantaranya sering diambil sebelum melahirkan. Dengan demikian, ibu yang bekerja hanya dapat mendampingi bayinya secara intensif hanya 2 (dua) bulan, termasuk dalam penyusuan bayinya. Setelah itu ibu harus kembali bekerja dan menyebabkan ibu terpaksa berhenti menyusui (Nugroho, 2011).

Hasil penelitian Xiang et al. (2016) menunjukkan bahwa ibu yang bekerja dalam 6 bulan pertama kelahiran bayi secara signifikan lebih besar untuk tidak memberikan ASI eksklusif kepada bayi dibandingkan dengan ibu yang tidak kembali bekerja. Selain itu usia ibu yang lebih tua, tingkat pendidikan yang lebih tinggi, kesehatan fisik atau metal yang lebih baik secara signifikan berkontribusi pada peningkatan menyusui asi secara eksklusif. Penelitian serupa oleh Weber et al. (2011) menyatakan bahwa kembali bekerja adalah alasan utama berhenti menyusui, dari 60 persen ibu yang berniat terus menyusui namun hanya 40 persen yang berhasil menyusui kembali. Selain itu, pada penelitian Queluz et al. (2012) menyatakan bahwa ibu yang berusia lebih muda dari 20 tahun memiliki peluang lebih besar untuk menghentikan pemberian ASI eksklusif.

Tindak lanjut dari pemerintah untuk meningkatkan cakupan ASI eksklusif dengan menerbitkan Peraturan Pemerintah nomor 33 tahun 2012 dan Peraturan Daerah Kota Yogyakarta nomor 1 tahun 2014 mengenai pemberian ASI eksklusif.

Cakupan pemberian ASI eksklusif di Daerah Istimewa Yogyakarta (DIY) tahun 2017 sebesar 75,03\% dan mengalami penurunan tahun 2018 sebesar $67,55 \%$. Pemberian ASI eksklusif paling rendah di Daerah Istimewa Yogyakarta terjadi di Kota Yogyakarta. Pada tahun 2015 cakupan ASI eksklusif di Kota Yogyakarta sebesar 60,87\% dan mengalami penurunan di tahun 2016 sebesar 59,52\%. Pada tahun 2017 cakupan ASl eksklusif di Kota Yogyakarta meningkat menjadi $61,52 \%$, jumlah pemberian ASI eksklusif ini merupakan jumlah terendah dibandingkan dengan Kabupaten lain yang ada di DIY (Dinas Kesehatan Provinsi DIY, 2018)

Puskesmas Umbulharjo 1 merupakan puskesmas dengan cakupan ASI eksklusif terendah di Kota Yogyakarta. Pada tahun 2015 sebesar 45,80\%, tahun 2016 sebesar 35,47\%, dan pada tahun 2017 cakupan ASI eksklusif di puskesmas Umbulharjo 1 sebesar 39,15\% (Dinkes Kota Yogyakarta, 2017). Pencapaian tersebut masih rendah dibandingkan dengan target Rencana Strategis Dinas Kesehatan Kota Yogyakarta sebesar $60 \%$ dan target ASI eksklusif nasional $80 \%$. 
Berdasarkan uraian di atas, peneliti telah melaksakan penelitian mengenai hubungan umur dan pekerjaan ibu dengan pemberian ASI eksklusif di wilayah kerja Puskesmas Umbulharjo 1 Kota Yogyakarta.

\section{Metode}

Desain penelitian yang digunakan pada penelitian ini adalah survey analitik dengan pendekatan cross sectional. Populasi dalam penelitian ini adalah semua ibu yang mempunyai bayi umur 6-12 bulan di wilayah kerja Puskesmas Umbulharjo 1 Kota Yogyakarta yang berjumlah 179 bayi. Jumlah sampel dalam penelitian ini 64 ibu yang mempunyai bayi umur 6-12 bulan.

Teknik pengambilan sampel menggunakan cluster sampling (area sampling) di masingmasing Kelurahan Wilayah Kerja Puskesmas Umbulharjo I yaitu kelurahan Pandeyan, Sorosutan dan Giwangan. Setelah dilakukan perhitungan sampel di masing masing wilayah, maka didapatkan sampel sebanyak 64 ibu yang mempunyai bayi 6-12 bulan. Pengambilan sampel dilakukan secara acak (random). Penelitian ini telah dilaksanakan pada bulan JuniAgustus 2018.

Instrumen pengambilan data dalam penelitian ini menggunakan data primer (kuesioner). Kuesioner berisi pertanyaan pekerjaan ibu, umur ibu dan pemberian ASI eksklusif. Untuk mengetahui baik tidaknya instrument kuesioner pada penelitian ini, maka peneliti telah melakukan uji validitas dan reliabilitas. Hasil uji validitas didiapatkan bahwa item pertanyaan dinyatakan valid dengan hasil $>0,444$. Sedangkan hasil uji reliabilitas didapatkan bahwa hasil alpha positif sebesar 0,8821 lebih besar dari 0,6 yang merupakan batas minimal koefisiensi reliabilitas bisa dianggap baik.

Pada penelitian ini variabel bebas (independent variable) mencakup umur dan pekerjaan, sedangkan variabel terikat (dependent variable) adalah pemberian ASI eksklusif. Analisa data menggunakan uji chi-square. Melalui perhitungan uji chi square maka akan ditarik suatu kesimpulan apakah ada hubungan atau tidak ada hubungan antara variabel dependen dengan variabel independen.

\section{Hasil dan Pembahasan}

Karakteristik responden dalam penelitian menunjukkan bahwa sebagian besar dari ibu yang mempunyai bayi umur 6-12 bulan memiliki paritas multipara sebanyak 42 orang $(65,6 \%)$, dan karakteristik pendidikan ibu didapatkan hasil bahwa sebagian besar ibu memiliki latar belakang pendidikan menengah (SMA/SMK) sebanyak 34 orang $(53,1 \%)$.

Hasil analisa data karakteristik ibu diketahui bahwa ibu memiliki paritas terbanyak yaitu multipara sebanyak 42 orang $(65,6 \%)$. Penelitian Mohamed et al. (2018) menunjukkan bahwa ibu multipara memiliki pengetahuan tentang menuyusui lebih baik sehingga tingkat pemberian ASI eksklusif lebih tinggi dibandingkan dengan ibu primipara. Tingkat pemberian ASI pada ibu multipara sebesar 49,3\% sedangkan pada ibu primipara $39,4 \%$. Sedangkan pada penelitian Velusamy et al. (2017) menyatakan bahwa didapatkan hubungan signifikan antara jumlah anak dalam keluarga dengan durasi pemberian ASI eksklusif. Ibu yang memiliki lebih dari satu anak, lebih cenderung tidak menyusui bayinya secara eksklusif. 
Hasil serupa telah dilaporkan oleh penelitian Arora et al. (2017) bahwa wanita multipara cenderung tidak menyusui dibandingkan dengan wanita yang primi. Hal ini dapat disebabkan oleh semangat dan rasa bangga serta bahagia telah memiliki buah hati untuk pertama kalinya dan apabila dibandingkan dengan ibu multipara yang telah mempunyai pengalaman menyusui sebelumnya, rata-rata ibu multipara ini memiliki pengalaman yang kurang menyenangkan tentang menyusui seperti payudara bengkak dan sakit karena menyusui.

Hasil analisis data karakteristik responden berdasarkan tingkat pendidikan diketahui responden terbanyak adalah responden dengan tingkat pendidikan SMA yaitu sebanyak 34 orang $(53,1 \%)$. Tingkat pendidikan yang baik akan mempengaruhi ibu dalam pemberian ASI eksklusif.

Dalam penelitian ini responden dengan pendidikan SMA lebih banyak dikarenakan sebagian besar responden merasa bahwa pendidikan yang dicapai sudah lebih tinggi. Dengan hanya pendidikan terakhir SMA responden merasa bahwa dapat menerima semua informasi yang disampaikan. Hubungan pendidikan dengan pola pikir dan persepsi serta perilaku masyarakat sangat signifikan, bahwa semakin tinggi tingkat pendidikan seseorang maka semakin rasional dalam pengambilan berbagai keputusan.
Hasil penelitian Acharya dan Khanal (2015) menyatakan bahwa peluang menyusui lebih tinggi di antara ibu dengan pendidikan menengah atau tinggi dibandingkan dengan ibu yang tidak berpendidikan. Tingkat pendidikan ibu dapat mendukung keberhasilan ASI eksklusif pada bayi balita. Semakin tinggi tingkat pendidikan seseorang semakin mudah menerima informasi (Hartini, 2014).

Berdasarkan Tabel 1. tersebut menunjukkan bahwa responden dengan umur $<20$ atau 35> yang memberikan ASI eksklusif sebanyak 5 orang $(7,8 \%)$. Sedangkan responden dengan umur $<20$ atau 35> yang tidak memberikan ASI eksklusif sebanyak 20 orang (31,3\%). Responden dengan umur 20-35 yang memberikan ASI eksklusif sebanyak 21 orang (32,8\%), sedangkan responden dengan umur 20-35 yang tidak memberikan ASl eksklusif sebanyak 18 orang (28,1\%).

Hasil uji Chi-Square yaitu $p$-value menunjukan hasil 0,007 . Sehingga dapat disimpulkan bahwa $p$ values $0,007<0,05$ dan terdapat hubungan antara umur ibu dengan pemberian ASI eksklusif di Wilayah Kerja Puskesmas Umbulharjo 1 tahun 2018. Nilai koefisien kontingensi didapatkan hasil bahwa $\mathrm{C}=0,319$, yang artinya tingkat keeratan hubungan koefisien kontingensi adalah rendah $(0,20-0,399)$.

Tabel 1. Hubungan antara Umur Ibu dengan Pemberian ASI Eksklusif Tahun 2018

\begin{tabular}{|c|c|c|c|c|c|c|c|c|}
\hline \multirow{3}{*}{ Umur Ibu } & \multicolumn{4}{|c|}{ Pemberian ASI Eksklusif } & \multicolumn{2}{|c|}{ Total } & \multirow[t]{3}{*}{$P$-value } & \multirow[t]{3}{*}{ OR } \\
\hline & \multicolumn{2}{|c|}{ Tidak ASI Eksklusif } & \multicolumn{2}{|c|}{ ASI Eksklusif } & \multirow[b]{2}{*}{$f$} & \multirow[b]{2}{*}{$\%$} & & \\
\hline & $\mathrm{F}$ & $\%$ & $\mathrm{~F}$ & $\%$ & & & & \\
\hline$<20$ dan $>35$ th & 20 & 31,3 & 5 & 7,8 & 25 & 39,1 & דחת ח & 0 \\
\hline $20-35$ th & 18 & 28,1 & 21 & 32,8 & 39 & 60,9 & $0,00 /$ & 0,319 \\
\hline Total & 38 & 59,4 & 26 & 40,6 & 64 & 100 & & \\
\hline
\end{tabular}


Tabel 2. Hubungan antara Pekerjaan dengan

Pemberian ASI Eksklusif Tahun 2018

\begin{tabular}{ccccccccc}
\hline \multirow{3}{*}{ Pekerjaan } & \multicolumn{3}{c}{ Pemberian ASI Eksklusif } & & \multirow{2}{*}{ Total } & \multirow{2}{*}{ P-value } & OR \\
\cline { 2 - 6 } & \multicolumn{2}{c}{$\begin{array}{c}\text { Tidak ASI } \\
\text { Eksklusif }\end{array}$} & \multicolumn{2}{c}{ ASI Eksklusif } & & & & \\
\cline { 2 - 7 } & $\mathrm{F}$ & $\%$ & $\mathrm{~F}$ & $\%$ & $\mathrm{f}$ & $\%$ & \\
\hline Bekerja & 28 & 43,8 & 7 & 10,9 & 35 & 54,7 & \multirow{2}{*}{0,000} & \multirow{2}{*}{0,419} \\
\hline Tidak Bekerja & 10 & 15,6 & 19 & 29,7 & 29 & 45,3 & & \\
\hline Total & 38 & 59,4 & 26 & 40,6 & 64 & 100 & & \\
\hline
\end{tabular}

Berdasarkan Tabel 2. tersebut menunjukkan bahwa responden yang bekerja dan memberikan ASI eksklusif sebanyak 7 orang (10,9\%). Sedangkan responden yang bekerja dan tidak memberikan ASI eksklusif sebanyak 28 orang (43,8\%). Responden yang tidak bekerja dan memberikan ASI eksklusif sebanyak 19 orang $(29,7 \%)$, sedangkan responden yang tidak bekerja dan tidak memberikan ASI eksklusif sebanyak 10 orang $(15,6 \%)$.

Hasil uji Chi-Square yaitu $p$-value menunjukan hasil 0,000. Sehingga dapat disimpulkan bahwa $p$ values $0,000<0,05$ dan terdapat hubungan pekerjaan ibu dengan pemberian ASI eksklusif di Wilayah Kerja Puskesmas Umbulharjo 1 tahun 2018. Nilai koefisien kontingensi didapatkan hasil bahwa $C=0,419$, yang artinya tingkat keeratan hubungan koefisien kontingensi adalah sedang $(0,40-0,599)$.

Hasil penelitian pada Tabel 1. menunjukkan bahwa ada 21 orang ibu yang memberikan ASI eksklusif merupakan ibu yang berumur antara 20-35 tahun (32,8\%). Sedangkan ada 20 orang ibu yang tidak memberikan ASI eksklusif yang merupakan ibu yang berumur <20 atau >35 tahun (31,3\%). Dalam hal ini berarti bahwa ibu yang berumur 20-35 tahun lebih cenderung memberikan ASI eksklusif sedangkan ibu yang berumur $<20$ atau >35 tahun lebih cenderung tidak memberikan ASI eksklusif.

Persentase ibu yang tidak memberikan ASI eksklusif sebesar 59,4\%, sedangkan yang memberikan ASI eksklusif sebesar 40,6\%. Hal ini menunjukkan bahwa persentase pemberian ASI eksklusif masih dibawah target nasional yaitu $80 \%$, sehingga cakupan yang dicapai di Puskesmas Umbulharjo 1 belum memenuhi target nasional. Setelah dilakukan analisis data dengan uji Chi Square didapatkan nilai p sebesar $0,007(p<0,05)$, menunjukkan bahwa hipotesis yang menyatakan ada hubungan umur ibu dengan pemberian ASI eksklusif dapat diterima. Hal ini berarti ada hubungan antara umur ibu dengan pemberian ASI eksklusif di Puskesmas Umbulharjo 1 Kota Yogyakarta.

Hal ini sesuai dengan hasil penelitian Conita (2014) bahwa adanya hubungan mengenai pengaruh umur ibu terhadap pemberian ASI eksklusif. Ibu yang memiliki umur diatas 30 tahun memiliki jumlah anak yang lebih banyak sehingga pemberian ASI eksklusif tidak tercapai. Demikian juga dengan proporsi menyusui yang semakin menurun. 
Selain itu, disebabkan oleh pengalaman menyusui sebelumnya, ibu tidak memberikan ASI eksklusif kepada bayinya dan bayi tetap sehat sehingga menyebabkan ibu juga tidak memberikan ASI eksklusif kepada anak berikutnya. Sebaliknya pada kelompok umur 20-35 tahun termasuk kelompok umur reproduksi sehat sehingga ibu mampu memecahkan masalah-masalah yang dihadapi dengan lebih matang secara emosional, terutama dalam menghadapi kehamilan, persalinan, nifas dan merawat bayinya.

Hasil penelitian Asfaw et al. (2015) menyatakan peluang ibu yang berusia 25 hingga 35 tahun untuk memberikan ASI eksklusif adalah 8,9 kali lebih banyak dibandingkan ibu yang berusia kurang dari 25 tahun. Hal ini bisa disebabkan oleh fakta bahwa ibu yang berusia lebih muda memiliki kesempatan kerja yang lebih baik dan tidak memiliki waktu untuk memberikan ASI eksklusif kepada bayinya.

Penelitian serupa dari Queluz et al. (2012) menyatakan bahwa ibu yang berusia lebih muda dari 20 tahun memiliki peluang lebih besar untuk menghentikan pemberian ASI eksklusif.

Penelitian Zielinska dan Hamulka (2018) menyatakan bahwa faktor risiko tertinggi untuk tidak memberikan ASI eksklusif adalah usia ibu $<20$ tahun dan memiliki pengetahuan menyusui yang tidak memadai, sedangkan risiko terendah dikaitkan dengan niat sebelum hamil untuk menyusui, pengetahuan yang sangat baik tentang menyusui dan usia ibu 26-30 tahun. Penelitian ini mengungkapkan peningkatan risiko tidak memberikan ASI eksklusif sebesar 6 kali pada ibu $<20$ tahun, sedangkan ibu berusia 26-30 tahun memiliki risiko setengah lebih rendah daripada usia $<20$ tahun.
Hal tersebut didukung oleh penelitian Behera dan Anil Kumar (2015) (menyatakan bahwa ibu yang berusia >20 tahun atau yang lebih tua memiliki niat menyusui eksklusif yang lebih tinggi daripada ibu yang lebih muda atau berusia $<20$ tahun. Studi ini menunjukkan bahwa ibu yang berusia lebih tua memiliki niat yang lebih kuat untuk menyusui eksklusif mungkin karena pengetahuan yang lebih baik dan kontrol yang lebih tinggi.

Hasil penelitian pada Tabel 2. menunjukkan bahwa hampir setengah dari responden di wilayah kerja Puskesmas Umbulharjo 1 Kota Yogyakarta merupakan ibu yang tidak bekerja dan memberikan ASl eksklusif sebanyak 19 orang $(29,7 \%)$. Sedangkan hampir setengah dari responden juga merupakan ibu yang bekerja dan tidak memberikan ASI eksklusif sebanyak 28 orang $(43,8 \%)$. Dalam hal ini berarti bahwa ibu yang tidak bekerja lebih cenderung memberikan ASI eksklusif sedangkan ibu yang bekerja lebih cenderung tidak memberikan ASI eksklusif.

Setelah dilakukan analisis data dengan uji $\mathrm{Chi}$ Square didapatkan nilai $p$ sebesar $0,000(p<0,05)$, menunjukkan bahwa hipotesis yang menyatakan ada hubungan pekerjaan ibu dengan pemberian ASI eksklusif dapat diterima. Hal ini berarti ada hubungan antara pekerjaan ibu dengan pemberian ASI eksklusif di Puskesmas Umbulharjo 1 Kota Yogyakarta.

Menurut penelitian Juliastuti (2011) pemberian ASI secara eksklusif akan semakin tinggi jika ibu tidak bekerja. Hal tersebut karena ibu yang tidak bekerja hanya menjalankan fungsinya sebagai ibu rumah tangga dan banyak menghabiskan waktunya dirumah tanpa terikat pekerjaan di luar rumah sehingga dapat mem- 
berikan ASI secara optimal tanpa dibatasi oleh waktu dan kesibukan.

Hal ini didukung dengan penelitian Setegn et al. (2011) menyatakan bahwa ibu yang tidak bekerja lima kali lebih mungkin memberikan ASI eksklusif dibandingkan dengan ibu yang bekerja. Hasil penelitian serupa oleh Weber et al. (2011) menyatakan bahwa kembali bekerja adalah alasan utama berhenti menyusui, dari $60 \%$ wanita yang berniat terus menyusui namun hanya $40 \%$ yang melakukannya.

Hasil penelitian Asfaw et al. (2015) menyatakan ibu yang dipekerjakan ditemukan 0,36 kali lebih kecil kemungkinannya untuk memberikan ASI eksklusif daripada ibu rumah tangga. Ini dapat dijelaskan oleh hukum perburuhan nasional Ethiopia yang memberikan cuti hamil selama dua bulan kepada para ibu. Cuti hamil pendek dan kondisi kerja yang tidak menguntungkan untuk melanjutkan ASI eksklusif mungkin menjadi penyebab praktik penyapihan dini para ibu. Ibu yang ibu rumah tangga lebih baik dalam mempraktikkan pemberian ASI eksklusif daripada ibu yang dipekerjakan. Hal ini dikarenakan kondisi ibu yang memiliki lebih banyak waktu untuk bersama bayinya, memiliki lebih banyak kesempatan untuk memberikan ASI eksklusif daripada mereka yang tidak memiliki kesempatan karena pekerjaan atau alasan lain.

Penelitian ini juga didukung oleh penelitian Dearden et al. (2002) menyatakan bahwa risiko tidak menyusui secara eksklusif adalah 14,0 kali lebih besar untuk wanita yang kembali bekerja dari pada wanita yang tidak bekerja.

Penelitian serupa dari Queluz et al. (2012) menyatakan bahwa ibu yang bekerja diluar rumah tanpa cuti hamil, ibu yang tidak bekerja di luar rumah, ibu remaja, dan penggunaan dot memiliki peluang lebih besar untuk menghentikan pemberian ASI eksklusif. Hasil penelitian ini mengungkapkan bahwa perempuan yang memiliki pekerjaan dibayar tanpa cuti hamil memiliki sekitar tiga kali lebih banyak kesempatan untuk menghentikan pemberian ASI eksklusif, sementara perempuan yang tidak memiliki pekerjaan yang dibayar (gaji), memiliki kesempatan dua kali lebih banyak untuk menyapih dini.

Hasil penelitian Tewabe et al. (2016) menyatakan bahwa ibu yang tidak bekerja lebih mungkin untuk memberikan ASI eksklusif dibandingkan dengan ibu yang bekerja. Hal ini berkaitan dengan status ekonomi, dimana ibu yang berpenghasilan lebih rendah tidak memiliki pilihan lain untuk membeli makanan kepada bayinya, solusinya yaitu memberikan ASI kepada bayi. Sebaliknya untuk ibu yang dipekerjakan cenderung tidak menyusui bayinya secara eksklusif karena cuti hamil yang singkat, kurangnya waktu, jarak tempat kerja dari rumah, kurangnya ruang pribadi untuk menyusui atau mengeluarkan ASI di tempat kerja, jadwal kerja yang tidak fleksibel, dan tidak adanya pusat penitipan anak di lokasi kerja atau di dekat lokasi kerja.

Hal ini didukung oleh penelitian Mangrio et al. (2018) menyatakan bahwa ibu yang kembali bekerja dalam 12 minggu pascapersalinan memiliki peluang lebih tinggi untuk penyapihan dini pada bayinya dibandingkan pada ibu yang tidak bekerja.

\section{Kesimpulan}

Berdasarkan hasil penelitian didapatkan hasil bahwa terdapat hubungan antara umur dan 
pekerjaan ibu dengan pemberian ASI eksklusif di wilayah kerja Puskesmas Umbulharjo 1 Kota Yogyakarta. Dengan adanya hasil penelitian ini, diharapkan dapat membantu ibu menyusui memahami pentingnya pemberian ASI eksklusif dan dapat menyusui bayinya sampai umur dua tahun. Diharapkan ibu menyusui lebih aktif dalam mengakses informasi mengenai pentingnya pemberian ASI eksklusif bagi bayi, sehingga menumbuhkan motivasi ibu untuk berperilaku baik dalam memberikan ASI eksklusif. Selain itu, petugas kesehatan khususnya bidan diharapkan dapat meningkatkan peran aktif masyarakat dalam pemberian ASI eksklusif dengan memberikan penyuluhan atau konseling ASl eksklusif. [].

\section{Daftar Pustaka}

Acharya, P., \& Khanal, V. (2015). The effect of mother's educational status on early initiation of breastfeeding: Further analysis of three consecutive Nepal Demographic and Health Surveys. BMC Public Health, 15(1), 1069. https://doi.org/10.1186/s12889-0152405-y

Arora, A., Manohar, N., Hayen, A., Bhole, S., Eastwood, J., Levy, S., \& Scott, J. A. (2017). Determinants of breastfeeding initiation among mothers in Sydney, Australia: Findings from a birth cohort study. International Breastfeeding Journal, 12(1), 39. https://doi.org/10.1186/s13006-017-0130-0

Asfaw, M. M., Argaw, M. D., \& Kefene, Z. K. (2015). Factors associated with exclusive breastfeeding practices in Debre Berhan District, Central Ethiopia: A cross sectional community based study. International
Breastfeeding Journal, 10(1), 23. https://doi.org/10.1186/s13006-015-0049-2

Badan Kependudukan dan Keluarga Berencana Nasional. (2018). Laporan Survei Demografi dan Kesehatan Indonesia, 2017. https://www.bps.go.id/. https://ekoren.bkkbn.go.id/wpcontent/uploads/2018/10/Laporan-SDKI2017-WUS.pdf

Behera, D., \& Anil Kumar, K. (2015). Predictors of exclusive breastfeeding intention among rural pregnant women in India: a study using theory of planned behaviour. Rural and remote health, 15(3), 3405.

BPS. (2016). Statistik Indonesia 2016. Jakarta: Badan Pusat Statistik.

Dearden, K. A., Quan, L. N., Do, M., Marsh, D. R., Pachón, H., Schroeder, D. G., \& Lang, T. T. (2002). Work outside the home is the primary barrier to exclusive breastfeeding in rural Viet Nam: Insights from mothers who exclusively breastfed and worked. Food and Nutrition Bulletin, 23(4_suppl2), 99-106. https://doi.org/10.1177/15648265020234S2 14

Dinas Kesehatan Provinsi DIY. (2018). Profil kesehatan Provinsi Daerah Istimewa Yogyakarta.

Dinkes Kota Yogyakarta. (2017). Profil kesehatan Kota Yogyakarta 2017.

Hartini, S. (2014). Hubungan tingkat pendidikan ibu dengan keberhasilan ASI eksklusif pada bayi umur 6-12 bulan di Puskesmas Kasihan II Yogyakarta. Sekolah Tinggi IImu Kesehatan 'Aisyiyah Yogyakarta.

Juliastuti, R. (2011). Hubungan tingkat pengetahuan, status pekerjaan ibu, dan pelaksanaan inisiasi menyusu dini dengan pemberian ASI 
eksklusif. Universitas Sebelas Maret Surakarta.

Kementerian Kesehatan RI. (2018). Profil Kesehatan Indonesia 2018. pusdatin.kemkes.go.id. https://pusdatin.kemkes.go.id/resources/do wnload/pusdatin/profil-kesehatanindonesia/PROFIL_KESEHATAN_2018_1.pdf

Mangrio, E., Persson, K., \& Bramhagen, A.-C. (2018). Sociodemographic, physical, mental and social factors in the cessation of breastfeeding before 6 months: A systematic review. Scandinavian Journal of Caring Sciences, 32(2), 451-465. https://doi.org/ $10.1111 /$ scs.12489

Mohamed, M. J., Ochola, S., \& Owino, V. O. (2018). Comparison of knowledge, attitudes and practices on exclusive breastfeeding between primiparous and multiparous mothers attending Wajir District hospital, Wajir County, Kenya: A cross-sectional analytical study. International Breastfeeding Journal, 13(1), 11. https://doi.org/10.1186/s13006018-0151-3

Notoatmodjo, S. (2003). Pengantar pendidikan kesehatan dan perilaku kesehatan. Jakarta: Rineka Cipta.

Nugroho, T. (2011). ASI dan tumor payudara. Yogyakarta: Nuha Medika.

Queluz, M. C., Pereira, M. J. B., Santos, C. B. dos, Leite, A. M., \& Ricco, R. G. (2012). Prevalência e determinantes do aleitamento materno exclusivo no município de Serrana, São Paulo, Brasil. Revista da Escola de Enfermagem da USP, 46(3), 537-543. https://doi.org/ 10.1590/S0080-62342012000300002

Setegn, T., Gerbaba, M., \& Belachew, T. (2011). Determinants of timely initiation of breastfeeding among mothers in Goba Woreda, South East Ethiopia: A cross sectional study. BMC Public Health, 11(1),
217. https://doi.org/10.1186/1471-2458-11217

Tewabe, T., Mandesh, A., Gualu, T., Alem, G., Mekuria, G., \& Zeleke, H. (2016). Exclusive breastfeeding practice and associated factors among mothers in Motta town, East Gojjam zone, Amhara Regional State, Ethiopia, 2015: A cross-sectional study. International Breastfeeding Journal, 12(1), 12. https:// doi.org/10.1186/s13006-017-0103-3

UNICEF - Departemen Kesehatan RI Direktorat Jendral Bina Kesehatan Masyarakat Direktorat Gizi Masyarakat. (2009). Petunjuk praktis bagi kader dalam mendampingi ibu menyusui. Jakarta: Depkes RI.

Velusamy, V., Premkumar, P. S., \& Kang, G. (2017). Exclusive breastfeeding practices among mothers in urban slum settlements: pooled analysis from three prospective birth cohort studies in South India. International Breastfeeding Journal, 12(1), 35. https://doi.org/10.1186/s13006-017-0127-8

Weber, D., Janson, A., Nolan, M., Wen, L., \& Rissel, C. (2011). Female employees' perceptions of organisational support for breastfeeding at work: Findings from an Australian health service workplace. International Breastfeeding Journal, 6(1), 19. https://doi.org/ 10.1186/1746-4358-6-19

Xiang, N., Zadoroznyj, M., Tomaszewski, W., \& Martin, B. (2016). Timing of return to work and breastfeeding in Australia. Pediatrics, 137(6), e20153883-e20153883. https:// doi.org/10.1542/peds.2015-3883

Zielinska, M. A., \& Hamulka, J. (2018). Reasons for non-exclusive breast-feeding in the first 6 months. Pediatrics International, 60(3), 276281. https://doi.org/10.1111/ped.13480 